\title{
New segregate species and subspecies from the Grevillea victoriae (Proteaceae: Grevilleoideae) aggregate from south-east New South Wales
}

\author{
R.O. Makinson
}

\begin{abstract}
Makinson, R.O. (Australian National Herbarium, GPO Box 1600, Canberra ACT 2601, Australia; email: rom@anbg.gov.au) 1997. New segregate species and subspecies from the Grevillea victoriae (Proteaceae: Grevilleoideae) aggregate from south-east New South Wales. Telopea 7(2): 129-138. Two segregate species are separated from the aggregate of taxa around Grevillea victoriae F. Muell. G. oxyantha subsp. oxyantha, G. oxyantha subsp. ecarinata, G. rhyolitica subsp. rhyolitica, and G. rhyolitica subsp. semivestita are described and named, with notes on distribution and conservation status.
\end{abstract}

\section{Introduction}

The aggregate of taxa around Grevillea victoriae F. Muell. has proved to be one of the taxonomically more intractable complexes in the genus. Mueller (1855a: 107) named G. victoriae from Victorian collections made on the 'Buffalo Range, on the summits of Mt Buller and Mt Tambo, on the sources of the Mitta Mitta, at Mt Hotham and Mt Latrobe'. In the same month, he (1855b: 132) named G. miqueliana from Victorian collections near Mt McMillan and on the upper Avon River; this was characterised as having a 'grey-downy' perianth, a scabrous leaf upper surface, and tomentose branchlets, floral rachis, and leaf undersurface, in contrast to G. victoriae, which has a smooth leaf upper surface, and a 'silky' (sericeous or subsericeous) indumentum on the other organs mentioned.

Bentham (1870: 423, 467) recognised material from Mt Tambo as G. brevifolia F. Muell. ex Benth., later reduced to varietal rank within G. victoriae by Maiden and Betche (1916: 60). Bentham (op. cit.: 468) also tentatively recognised G. victoriae var. leptoneura Benth. from the upper Genoa River, near the Victorian border with New South Wales.

In the period since, the species names G. victoriae and G. miqueliana have been applied with varying degrees of consistency to a range of specimens and populations, from the ranges of eastern Victoria and south-eastern N.S.W., all clearly related, but varying considerably in foliar and floral features.

McGillivray (1993: 320-324) delimited eleven 'races' within a broadly circumscribed G. victoriae, including a taxon from eastern Queensland since named as G. hockingsii Molyneux \& Olde (1994: 784). Since McGillivray's treatment was finalised, the specimen base available has broadened considerably, but the aggregate as a whole remains only partially resolved, and with only sketchy indications of phylogeny. The aggregate is currently under study by Stajsic, Whiffin, and Molyneux, working from La Trobe University in Melbourne, using phytochemical and morphological characters. The present study, oriented to the production of a Flora of Australia treatment to be published in 1997, has proceeded in parallel with the Victorian work.

Two of McGillivray's races (races ' $j$ ' and ' $k$ '), both endemic to Victoria, had previously been more or less consistently identified by various workers as G. miqueliana F. Muell., 
the Type of that name belonging to 'race j'. This assigment has been continued by more recent workers (Olde \& Marriott 1995: 31-32, Makinson 1996: 852).

A further taxon, endemic to the far SE of N.S.W. (Nullica State Forest area $\mathrm{N}$ to Yowrie), is G. sp. aff. miqueliana 'Nullica' (D. Albrecht 2068; MEL, CBG, NSW), which equates to 'G. victoriae race 1 ' of McGillivray (1993) and to 'G. sp. aff. miqueliana (Yowaka and Yowrie)' of Olde \& Marriott (1995). This has a scabrid upper leaf surface, villous lower leaf surface, and tomentose to villous outer perianth surface in common with G. miqueliana, but has narrowly oblong-obovate (rather than elliptical) leaves. Its relationship to G. miqueliana sens. str., and to other members of the aggregate, is currently under investigation by Stajsic et al.

Two of McGillivray's remaining taxa (races ' $a$ ' and ' $b$ ') have together long been known as the 'Canberra form' or 'Australian Capital Territory (ACT) form' of G. victoriae, and were treated by Olde \& Marriott (op. cit.: 225) as 'G. sp. aff. victoriae 'A". These are characterised by an acute subpyramidal limb of the flower bud, resulting from an acute apiculation of each tepal.

A further taxon endemic to N.S.W. (Araluen Valley and Deua National Park areas) was distinguished by McGillivray (loc. cit.) as 'race g', and by Olde \& Marriott (loc. cit.) as 'G. sp. aff. victoriae ' $\mathrm{B}$ '. This taxon was characterised as having a sparse indumentum on the leaf undersurface, and the indumentum of the outside of the perianth comprising both biramous and simple erect hairs.

The present paper gives names at species rank for the last two of the above entities (i.e. the 'Canberra form' and the Deua/Araluen taxon), each with two subspecies, in order to make at least these names available for the forthcoming Flora of Australia treatment of the genus (Makinson, in prep., publ. expected late 1997). It is not expected that the work of Stajsic et al. will necessitate further ranks or names for these taxa. The Flora treatment will remain somewhat tentative as regards circumscription of other taxa within the aggregate, pending results of their work.

\section{Taxonomy}

\section{Grevillea oxyantha Makinson, sp. nov.}

G. victoriae F. Muell. sensu stricto similis sed alabastris ad apicem acutis pyramidalibusque, foliis subtus tomentosis pilis crispis vel sinuatis, venis lateralibus subtus plus prominentibus, differt.

Type: New South Wales: Southern Tablelands (A.C.T. boundary): Brindabella Range c. 3 miles [4.8 km] N of Mt Franklin, R.D. Hoogland 8433, 6 Dec 1961; holo CANB; iso AD, BM, BRI, E, G, K, MEL, NE, NSW, P, PERTH; also (not seen): A, B, BISH, C, FI, L, M, NY, S, UC, US, W, Z.

Erect to spreading shrub (0.5-)1-3 m tall. Branchlets sub-angular becoming terete. Leaves entire, ovate to obovate or broadly so, occasionally suborbicular, 2-6 cm long, 15-35 mm wide, leathery-textured; apex usually obtuse with a short blunt mucro, or occasionally subacute with a similar mucro; upper surface smooth, minutely foveolate, lateral veins conspicuous; margin very shortly recurved; lower surface densely tomentose to subtomentose with short curled to wavy hairs, or (subsp. ecarinata) subsericeous with more or less straight mutually aligned hairs; venation of lower surface with the lateral veins conspicuous, at c. $45^{\circ}$ to the midvein. Conflorescences terminal (often on short axillary branchlets), decurved to pendulous, pedunculate, usually a short loose cluster or sometimes loosely cylindrical, few- to many-flowered; peduncles 2-20 mm long, subsericeous to subtomentose with pale 
brown or rarely rusty brown hairs; floral rachises 8-45 $\mathrm{mm}$ long, subsericeous to subtomentose with pale brown or rarely rusty brown hairs. Flowers acroscopic; pedicels 3-4.5 $\mathrm{mm}$ long; torus oblique to the pedicel at c. $30^{\circ}$; limb of flower bud acutely to bluntly subpyramidal, sometimes shortly apiculate, remaining erect until buds c. $1 \mathrm{~cm}$ long and then sharply deflexed; perianth after anthesis narrow and nearly straight below the limb, outer surface densely subsericeous to shortly subtomentose with brown or reddish brown \pm appressed hairs, inner surface bearded (dorsal tepals glabrous in basal $2 \mathrm{~mm}$ to base of ovary then with a \pm dense beard almost to the level of tepal separation, ventral tepals glabrous or nearly so from the base for 5-6 $\mathrm{mm}$ then with a short beard 1.5-2 $\mathrm{mm}$ long immediately below the level of tepal separation); nectary arcuate, projecting c. $0.5 \mathrm{~mm}$ above the toral rim, margin undulate or faintly 3-toothed; pistil 18-24 mm long; stipe of ovary 2-3.5 mm long, glabrous; ovary glabrous; style exserted from dorsal suture of perianth before release of style-end, afterwards nearly straight, minutely and sparsely pubescent or papillose in the apical 3-10 $\mathrm{mm}$; pollen-presenter lateral, sub-oblong to slightly obovate in plan view, 2.5-3 mm long, 1.7-2 mm wide, stigma distally off-centre with a decurrent ridge to the base. Follicle narrowly and obliquely ovoid to obliquely ellipsoid, 15-20 mm long, glabrous, smooth except for one or two longitudinal ridges on each side, faintly glaucous; style persistent.

The epithet is from Greek, 'oxy-', sharp, and 'anthos', a flower, referring to the acute pyramidal limb of the bud.

Flower colour: outer surface of perianth scarlet to crimson (the indumentum red to brownish), inner surface (partly displayed) pinkish red with pale hairs; style deep to pale red.

Distribution: G. oxyantha occurs in southern montane areas of N.S.W. (including NW areas of the A.C.T.), in the general area bounded by Wee Jasper, Tumut, Batlow, Mt Franklin, Brown Mtn, and Mongarlowe (i.e. mainly in the Brindabella, Tinderry, Jounama and Kybean Ranges). It does not occur in the Bimberi Range/Scabby Range system (the range of G. diminuta L.A.S. Johnson), nor in the main Snowy Mountains ranges (where it is replaced in similar habitats by G. victoriae F. Muell.).

Distinguishing features: G. oxyantha is distinguished by the pyramidal-acute limb of the flower bud from G. victoriae, G. miqueliana, G. sp. nov. aff. miqueliana 'Nullica', G. diminuta, G. rhyolitica, and G. hockingsii (all of which have a spheroidal to broadly ovoid, obtuse bud limb). The subsericeous to subtomentose indumentum of the outer surface of the perianth, and the smooth upper surface of the leaf are in contrast to those of G. miqueliana and G. sp. nov. aff. miqueliana 'Nullica', which have a subvillous to villous perianth and a scabrid upper leaf surface (the latter also has narrowly oblong-obovate leaves, and a shorter pistil 12-14 $\mathrm{mm}$ long). The pistil length of $18-24 \mathrm{~mm}$ in $\mathrm{G}$. oxyantha is in clear contrast to a length of $10-11 \mathrm{~mm}$ in G. diminuta, which also has smaller leaves (0.5-2 cm long) and is a generally lower, denser shrub to $1 \mathrm{~m}$ tall. G. rhyolitica has an open-subvillous or sparse, appressed indumentum on the leaf undersurface, elliptical leaves with a subacute apex, and a strongly tomentose to villous outer perianth surface with mixed biramous and simple erect (possibly glandular) hairs.

Affinities: in the absence of a comprehensive analysis of the G. victoriae aggregate of species, affinities are uncertain. On morphological grounds, it is here postulated that G. oxyantha is most closely related to G. victoriae sens. str. and to G. diminuta. Two subspecies of $G$. oxyantha are recognised. 


\section{Key to the subspecies}

Limb-segment of each tepal with a pronounced longitudinal keel along the midline of the outer surface; leaf undersurface densely tomentose to subtomentose (rarely almost subsericeous) with short tightly curled to wavy or curved hairs; floral rachises 8-13 mm long subsp. oxyantha

Limb-segment of each tepal not or scarcely keeled along the midline; leaf undersurface densely subsericeous to subtomentose with appressed to weakly ascending, more or less straight, mutually-aligned hairs; floral rachises (12-)20-45 mm long

subsp. ecarinata

\section{1a. Grevillea oxyantha Makinson subsp. oxyantha}

Spreading to erect shrub $0.5-3 \mathrm{~m}$ tall. Leaves broad-ovate or broad-elliptical or sometimes almost orbicular; apex obtuse with a small mucro, or rarely subacute; undersurface densely tomentose with short curled to wavy hairs or sometimes subtomentose with wavy to curved ascending hairs, rarely almost subsericeous. Floral rachises $8-13 \mathrm{~mm}$ long. Flower with the limb-segments of the tepals each strongly keeled along the external midline.

Illustrations: P. Olde \& N. Marriott, The Grevillea Book vol. 3: 224 (184C), 225 (184E) (1995).

G. oxyantha subsp. oxyantha corresponds to 'G. victoriae race a' of D.J. McGillivray, Grevillea: 320-4 (1993), and to 'G. sp. aff. victoriae A' (pro parte) of Olde \& Marriott, op. cit.: 225 (1995). It has also been widely known in the botanical and horticultural literature as the 'A.C.T. form' or 'Canberra form' of G. victoriae.

Variation: G. oxyantha subsp. oxyantha shows some variation, mostly on a NW to SE geographical gradient. The indumentum of the leaf undersurface varies, in populations in the Brindabella Range (closely tomentose with tightly curled hairs) to those more to the SE in the Tinderry Ra. and along the eastern scarp of the Tabelands (hairs increasingly wavy or curved rather than tightly curled). The latter populations are still distinguishable on this character from nearly all N.S.W. populations of G. victoriae, which have a fully appressed indumentum of straight mutually aligned hairs on the leaf undersurface.

Over most of the range, leaves are broad-ovate or broad-elliptical with an obtusemucronate apex. Elliptical, sometimes subacute, leaves are more common (though still occasional) in the Tinderries and to the SE; these are almost entirely absent from the Brindabella Range populations.

Shape and length of the pyramidal floral bud limb in subsp. oxyantha varies on the same NW/SE gradient, being most acute and longest (often apiculate) in the Brindabella Range and tending to be progressively shorter and somewhat blunter to the $\mathrm{E}$ and SE of the range, except in the Big Badja - Little Badja and Brown Mtn areas where it is again strongly pyramidal.

In the vicinity of Mt Franklin, the range of subsp. oxyantha abuts the northern limit of G. diminuta; no intergradation has been seen or recorded. In the far north of the range, subsp. oxyantha approaches to within a few kilometres the range (Baldy Range in the northern Brindabellas) of a small isolated population assignable to G. victoriae (obtuse bud limb, elliptical subacute leaves, appressed, more or less straight hairs on leaf undersurface). In the SE of the range (upper Wadbilliga River and Brown Mtn areas), there is again a geographical approach to G. victoriae, with the tendencies in leaf indumentum and bud-limb shape noted above suggesting possible gene flow. An apparent intermediate with G. rhyolitica is known from the Bendethera Mtn area in the 
west of Deua National Park (N. Taws 329; CANB, NSW); the specimen has midline keeling on the tepals, an obtuse bud limb, elliptical leaves, a sericeous leaf undersurface, and scattered simple erect hairs among the biramous hairs on the outer surface of the perianth.

Distribution: subsp. oxyantha occurs in southern montane areas of N.S.W. (including NW areas of the A.C.T.), with the main occurrences in the Brindabella Range (north from Mt Franklin, Tidbinbilla, and Booroomba Rocks), the Tinderry Ranges, at scattered localities between Captains Flat, Mongarlowe, and Snowball, and in the Kybean Range along the tablelands escarpment from a little north of Big Badja Mtn south to the Brown Mtn area inland from Bega.

Habitat and ecology: subsp. oxyantha grows in various situations, usually in or on the margins of open eucalypt forest in rocky sites, often near peaks or cliffs, sometimes near creeks, usually in skeletal soils over granite or quartzite. There are no records of vegetative reproduction, and it is almost certainly killed outright by fire, with regeneration from seed only. The flowers are heavily visited by nectarivorous birds and are assumed to be primarily bird-pollinated, although introduced honey bees (Apis melifera) may now play a role. Flowering is mainly from August to December, occasional in other months.

Conservation status: subsp. oxyantha occurs in several conservation reserves, including Namadgi National Park, Tinderry Range Conservation Reserve, and Wadbilliga National Park, and is moderately common, although tending to occur in small, somewhat sporadic populations. It is not considered to be under any current threat, although long-term fire regimes may be significant for local populations.

Selected specimens: New South Wales: Southern Tablelands (including A.C.T.): c. $2 \mathrm{~km} \mathrm{~N}$ of Mt Aggie, Brindabella Ra., L.A.S. Johnson 7262 \& B.G. Briggs (NSW); Bulls Head to Mt Gingera Rd, c. 4 miles [6 km] from Bulls Head, C. Totterdell, 19 June 1968 (CANB); Tidbinbilla Ra., E of Fishing Gap, L.G. Adams 607 (CANB, E, K, L, MEL, NSW, US); Tinderry Mts, $13.2 \mathrm{~km}$ by road ESE of Michelago on the Jerangle Rd, R. Coveny 6579 et al. (NSW); Tinderry Ra. on Michelago to Anembo rd, L.A. Craven 1971 (A, CANB, G, L, NSW, P, PERTH, RSA, SI, UC); between Snowball and Boggy Plain, c. 3 miles [5 km] W of Big Badja Mtn, L.A.S. Johnson NSW 98417, 5 Jan 1968 (NSW); Bumberry Ck on the Wadbilliga Fire Trail, R. Coveny 6598 et al., 3 Aug 1975 (CANB, NSW).

1b. Grevillea oxyantha subsp. ecarinata Makinson, subsp. nov.

G. oxyanthae Makinson subsp. oxyanthae affinis similisque sed parte apicali tepalorum carinam longitudinalem deficienti, foliis subtus subsericeis pilis strictis, rhachidibus floralibus longioribus (12-45 $\mathrm{mm}$ longis), differt.

Type: New South Wales: Southern Tablelands: Bulls Flat Creek, 10 miles [16 km] N of Snowy Mts Highway on Yarrangobilly to Goobarragandra rd, 10 miles [16 km] ENE of Talbingo, A.N. Rodd 1021, 31 Mar 1970; holo NSW; iso PERTH

Erect to spreading shrub to $2 \mathrm{~m}$ tall. Leaves ovate or elliptical to broadly so; apex subacute; undersurface densely subsericeous to subtomentose with loosely appressed to ascending hairs. Floral rachis (12-) 20-45 mm long. Flower with the limb-segments of the tepals not or scarcely keeled along the external midline.

The epithet is from the Latin 'ecarinatus', lacking a keel, in reference to the limbsegments of the tepals as compared to those of the type subspecies.

Subsp. ecarinata corresponds to 'G. victoriae race b' of D.J. McGillivray, Grevillea: 320-4 (1993), and to 'G. sp. aff. victoriae A' (pro parte) of Olde \& Marriott (op. cit.: 225).

In addition to the lack of a pronounced midline keel on the limb segments of the tepals, and the straighter ascending to appressed hairs of the leaf undersurface, subsp. ecarinata has a generally blunter (though still subpyramidal) bud-limb, more elliptical 
leaves with a generally subacute apex, and a generally much longer floral rachis than subsp. oxyantha. In these characters it is somewhat intermediate between $G$. oxyantha subsp. oxyantha and Snowy Mountains populations of G. victoriae, the range of which it approaches E of Yarrangobilly and Tumut. It does, however, possess to some degree the (assumed derived) character-states that are here taken as central to defining G. oxyantha (subpyramidal bud-limb, tendency for leaf undersurface hairs to be ascending rather than strictly appressed or felted-matted, and prominent lateral veins especially on the leaf undersurface).

Variation: on specimens and populations seen, there is little variation.

Distribution: occurs from Micalong Creek area near Wee Jasper (NW of Canberra), south to near Tumut and Bago State Forest near Batlow.

Habitat and ecology: poorly recorded, but subsp. ecarinata appears to grow in small localised populations in similar sites to the typical subspecies. Regeneration mode is uncertain, but probably from seed only. It is assumed to be bird-pollinated. Flowering occurs mainly August to December.

Conservation status: this subspecies remains relatively poorly known and is rarely collected. Considerable areas of the total range have been converted to conifer plantations or have undergone lesser forms of disturbance. The extent of occurrence of the subspecies in conservation reserves is unknown, although a small population is recorded from Kosciusko National Park on the Peak River. A conservation rating of 2Ei- is recommended pending further survey, following the scheme of Briggs \& Leigh (1996), in which ' 2 ' indicates a range of less than $100 \mathrm{~km}$, ' $E$ ' indicates a risk of disappearance from the wild within c. 20 years, and ' $i$ '' indicates a reserved population of unknown size.

Selected specimens: New South Wales: Southern Tablelands: Micalong Ck (near Wee Jasper via Tumut), W. Wingate Hall NSW 93294, 18 Oct 1944 (NSW); 15 miles [24 km] SE of Batlow, Bago State Forest, R.J. Allen NSW 58417, 25 Oct 1962 (NSW); Bago State Forest, S of Batlow, 'Z.M.' [Z. Mazanec] s.n., 10 Aug 1961 (CANB); Kosciusko NP, c. 25 km directly SE of Tumut, Peak R., 1 km upstream of junction with Waterfall Creek, N. Taws 236, 31 Oct 1993 (CANB, MEL, NSW); Jounama Ra., E. Gauba s.n., 11 Nov 1952 (CANB).

\section{Grevillea rhyolitica Makinson, sp. nov.}

G. victoriae F. Muell. et G. miquelianae F. Muell. similis sed foliis subtus indumento diffuso vel sparso, inflorescentiis pilis erectis simplicibus inter pilos dibrachiatos mixtis, differt.

Type: New South Wales: South Coast: Donald Creek near crossing of the Coondella Trig Road (new alignment), c. $4.5 \mathrm{~km}$ E of Coondella Trig, D. Albrecht 3993, 24 Mar 1990; holo MEL; iso CBG.

More or less erect, often gregarious shrub 0.5-2 $\mathrm{m}$ tall. Branchlets angular to subterete in cross-section, loosely to openly tomentose, with ascending to spreading biramous hairs and usually also with few to many simple erect, possibly glandular, hairs (the latter sometimes absent). Leaves narrowly to broadly elliptical, 4-11 cm long, 10-25 mm wide, thin-textured; apex subacute with a short blunt hairy mucro; upper surface of juvenile leaves with an open appressed or ascending indumentum of biramous hairs, of adult leaves smooth (lacking asperities), glabrous or with a few hairs especially near the midvein; lower surface with an open to sparse indumentum (ground tissue clearly visible between hairs), either of ascending biramous hairs and then often also with scattered minute simple erect glandular hairs, or of short-armed closely appressed biramous hairs only; venation with the midvein, lateral veins and sometimes some reticulum evident on both surfaces. Conflorescences terminal or subterminal axillary, simple or basally two-branched; unit conflorescence decurved to pendulous, acropetal 
to subsynchronous, (2-)5-18-flowered, a loose \pm regular ovoid to subglobose cluster; peduncle 15-20 mm long, thin, wiry; peduncle and floral rachis loosely to sparsely pubescent to tomentose with mixed biramous and erect simple (possibly glandular) hairs. Flowers acroscopic; pedicels $2-4 \mathrm{~mm}$ long, tomentose with brownish biramous hairs and usually also erect simple hairs; torus oblique at c. $30^{\circ}$; perianth in bud stage with the limb subglobose, obtuse; perianth outer surface after anthesis subsericeous to loosely tomentose (to densely so on limb segments) with mixed brownish biramous hairs and few to many erect, simple (possibly glandular) hairs; perianth inner surface glabrous near base, with a dense beard commencing just above ovary level and extending for 3.5-6 mm; nectary arcuate to sublinguiform, projecting c. $0.7 \mathrm{~mm}$ beyond the toral rim; pistil 16-20 mm long; stipe of ovary glabrous, $1.7-2.5 \mathrm{~mm}$ long; ovary glabrous; style with scattered minute erect simple hairs on the back of the styleend and in the apical few $\mathrm{mm}$, or occasionally (subsp. semivestita only?) over most of its length; pollen-presenter lateral on the style or nearly so, obovate to broadly so, often slightly emarginate on the distal rim, 2.3-3.0 mm long, 2.2-2.3 mm wide, shallowly concave, the stigma a slight, distally off-centre, papilloid boss. Follicle (subsp. rhyolitica only seen) slightly sigmoid when young, at maturity narrowly and obliquely ellipsoid, 18-22 mm long, with several longitudinal ridges especially near the apex; pericarp crustaceous, exocarp possibly exfoliating after seed fall; style persistent. Seeds not seen.

The epithet 'rhyolitica' refers to the occurrence (possibly obligate) of this species on outcrops of rhyolite rock.

Distribution: G. rhyolitica occurs in subcoastal montane areas of the New South Wales South Coast botanical district, from NW to SW of Moruya in Dampier State Forest and Deua National Park.

Distinguishing features and affinities: Grevillea rhyolitica is distinguished from closely related species by several floral and foliar features. Its most obvious characteristics are the combination of elliptical subacute leaves, smooth upper surface of the leaf, open indumentum (open-tomentose with ascending hairs, or open to sparse and appressed) of the lower leaf surface, and presence of erect simple hairs among the biramous hairs of the outer surface of the perianth (often also on the peduncles and floral rachises). G. victoriae has the indumentum of the leaf undersurface more or less densely subsericeous-appressed or irregularly felty, with biramous hairs only (simple erect hairs always lacking); the indumentum of the branchlets, peduncles, rachis, and outer surface of the perianth with biramous hairs only, the arms usually appressed or at most only weakly ascending; and the pistil often longer (to $26 \mathrm{~mm}$ long) and with a proportionately smaller pollen-presenter. G. miqueliana and G. sp. nov. aff. miqueliana 'Nullica' have the leaf apex obtuse, the leaf upper surface with granular asperities, and the leaf undersurface with a much denser, villous indumentum of biramous hairs only; the latter also has shorter pistils (12-14 mm long). G. linsmithii McGillivray and G. mollis Olde \& Molyneux are both similar but are geographically remote. G. linsmithii has obtuse, narrowly oblong to obovate leaves up to $10 \mathrm{~mm}$ wide, with a denser indumentum on the leaf undersurface, the perianth twotoned green and red in colour, and pistils 10-16 mm long. G. mollis has generally narrower leaves 4-14 mm wide, persistent spreading hairs on the leaf upper surface, fewer-flowered inflorescences, and the outer surface of the perianth with mainly erect simple hairs (biramous hairs few or absent).

G. rhyolitica has a close geographical, and possibly taxonomic, relationship with $G$. sp. aff. miqueliana 'Nullica' (D. Albrecht 2068, MEL, CBG, NSW), which has narrowly suboblong leaves 5-17 mm wide, with obtuse apices; the leaf upper surface granulate; and biramous hairs only on the branchlets, peduncles, floral rachises and outer surface of the perianth. This taxon, which equates to 'G. victoriae race l' of McGillivray (1993) and 
to 'G. sp. aff. miqueliana (Yowaka and Yowrie)' of Olde \& Marriott (1995) is likely to warrant recognition at species rank; the relationship with G. miqueliana is under investigation by Stasijc et al. It grows in similar habitats to G. rhyolitica, and somewhat to the south (from Nullica State Forest near Eden, north to the Tuross River valley near Belowra). At the latter locality it is within $30 \mathrm{~km}$ of the known range of G. rhyolitica. In the north of its range, some specimens have a more open indumentum on the leaf undersurface, perhaps indicative of an approach to G. rhyolitica, although this is not expressed in other characters. A more convincingly intermediate specimen, perhaps representing a genuine intergrade between the 'Nullica' taxon and G. rhyolitica, is represented by a single collection from the area inland from Narooma (Wadbilliga River above Wadbilliga Firetrail crossing, R. Outhred s.n., 19 Dec 1982, CBG); this specimen has elliptical sub-acute leaves like those of G. rhyolitica, but with the upper surface of the leaf granulate, the undersurface more or less densely subsericeous, and with leaves and flowers lacking erect simple hairs. G. rhyolitica has not been recorded so far to the south as yet, and the 'intermediate' population has not been relocated. An apparent intergrade of G. rhyolitica with G. oxyantha subsp. oxyantha (N. Taws 329, Bendethera Mtn area; CANB, NSW) is discussed under that taxon, above.

Two subspecies of G. rhyolitica are here recognised:

\section{Key to the subspecies}

Leaf undersurface with an open indumentum of ascending biramous hairs (often also with simple erect ?glandular hairs); outer surface of perianth with simple erect hairs (mixed among ascending biramous hairs) usually confined to the basal third, occasionally more extensive. subsp. rhyolitica

Leaf undersurface with scattered minute closely appressed biramous hairs (surface sometimes appearing glabrous); outer surface of perianth with simple erect hairs (mixed among ascending biramous hairs) distributed over the whole surface, including limb segments. subsp. semivestita

\section{2a. Grevillea rhyolitica subsp. rhyolitica}

Shrub to $2 \mathrm{~m}$ tall. Branchlets initially angular to subterete in cross-section, rapidly becoming obscurely angular to subterete, open-tomentose, usually with a mixture of non-glandular brownish biramous hairs, and simple erect, pale, possibly glandular, hairs (sometimes only the latter). Leaves elliptical to narrowly (rarely broadly) so, (4.5-)5.5-11 cm long, 10-25 mm wide; undersurface with an open indumentum of ascending biramous hairs usually denser along the midvein, often also with few to many scattered minute erect simple hairs. Peduncles and floral rachises loosely tomentose with biramous hairs and usually also numerous simple erect hairs (sometimes the latter predominating). Outer surface of perianth loosely tomentose (to densely so on limb), with mainly biramous ascending hairs and usually also relatively few simple erect hairs, the latter usually confined to the basal third and inconspicous, or rarely (e.g. Walsh 1875; MEL, NSW) extending over the whole outer surface.

Subsp. rhyolitica corresponds to G. victoriae 'Unassigned 7' of McGillivray (1993:322), and to G. sp. aff. victoriae 'B' (in part) of Olde \& Marriott (1995:225).

Flower colour: perianth and style red.

Distribution: occurs in montane areas west and south-west of Moruya, in Dampier State Forest and Deua National Park, on the catchments of Donalds Creek and the Coondella Creek-Burra Creek system (all tributaries of the Deua River from the south). 
Habitat and ecology: recorded from open eucalypt forest (associations noted are Eucalyptus sieberi 'Silvertop Ash' with E. stenostoma 'Jilliga Ash'), from riparian forest with Tristaniopsis laurina and Lomatia myricoides, and from mixed sclerophyll shrubland. The species occurs at 100-600 m alt., in both moist gully and steep rocky ridge situations, with southern and north-western aspects, in skeletal soils on rhyolite (Comerong Volcanics group). It is almost certainly killed by fire and regenerant from seed only. It is assumed to be primarily bird-pollinated. Flowering is recorded for Sept.-Dec.

Selected specimens: New South Wales: South Coast: 'Mountains of the Moon', Deua National Park, G. Moran 110 \& L. Thomson (CBG); Deua National Park, c. 2 km N of Coondella Trig, P. Gilmour 4320 (CBG); Dampier State Forest, c. 22 km W of Moruya, R. Pullen 4758 (CANB - 2 sheets); Deua National Park, prominence $1.9 \mathrm{~km}$ N of Coondella Trig, N. Walsh 1875 (CANB, MEL).

\section{2b. Grevillea rhyolitica subsp. semivestita Makinson, subsp. nov.}

Type: New South Wales: South Coast: Araluen Valley, E. Gauba CBG 005044, 3 Aug 1953; holo CANB.

Grevillea rhyoliticae subsp. rhyoliticae similis sed foliis plerumque paulo latioribus subtus indumento appresso, diffuso vel sparso ex pilis dibrachiatis solum constantibus, differt.

Shrub to $1 \mathrm{~m}$ tall. Branchlets angular, loosely subsericeous with appressed shortarmed biramous hairs only. Leaves elliptical, (4-)6-11 cm long, 12-23 mm wide; lower surface often appearing glabrous but with an open inconspicuous indumentum of very short-armed appressed biramous hairs (erect simple hairs lacking), most hairs ferruginous, some pale, lateral veins evident. Peduncles and floral rachises loosely to sparsely pubescent with mainly simple erect hairs and often also a few ascending biramous hairs. Outer surface of perianth loosely tomentose with brownish ascending biramous hairs mixed with numerous weakly erect simple, ?glandular pale hairs, the latter distributed more or less evenly from base to limb.

The epithet is from the Latin 'semi-', half, and 'vestitus', clad or clothed, in reference to the open to sparse indumentum of the leaf undersurface.

Subsp. semivestita corresponds to G. victoriae 'race g' of McGillivray (1993:320-4), and to G. sp. aff. victoriae 'B' (in part) of Olde \& Marriott (1995:225)

Flower colour: perianth and style red.

Distribution: occurs in the northern part of the species' range, in coastal mountain ranges NW of Moruya, recorded from the NE slopes of Mt Donovan (Oulla Ck catchment) and from 'Araluen Valley'.

Habitat \& ecology: grows in broken escarpment country, recorded from steep upper slopes below rock outcrops in skeletal soils on rhyolite, in open Eucayptus sieberi forest. This subspecies is apparently fire-sensitive, regenerating from seed only, and birdpollinated. Flowering is recorded for Oct.-Dec.

Selected specimens: New South Wales: South Coast: Deua National Park, ridge running off Mt Donovan, $1.8 \mathrm{~km}$ NE of summit, c. $20 \mathrm{~km}$ WNW of Moruya, P. Beesley 391 \& D. Binns (CBG, NSW); Araluen Valley, Mrs Shoobridge CBG 006729, Sep 1964 (CBG, NSW).

\section{Acknowledgments}

Thanks are due to Bill Molyneux, Don McGillivray, David Albrecht, and Peter Olde for many useful discussions on the G. victoriae complex; to Peter G. Wilson (NSW) for assistance with the Latin; and to the Directors of Herbaria BM, E, G, K, MEL, BRI, and 
NSW for access to collections. This paper was substantially written during a posting as Australian Botanical Liaison Officer at Royal Botanic Gardens, Kew, UK, funded by the Australian Biological Resources Study and by the Australian National Botanic Gardens; my appreciation and thanks goes to these organisations.

\section{References}

Bentham, G. (1870) Flora Australiensis, vol. 5. (Reeve: London).

Briggs, J.D., \& J.H. Leigh (1996) Rare or Threatened Australian Plants, revised edition. (CSIRO Publishing: Collingwood).

McGillivray, D.J. (1993) Grevillea. (Melbourne University Press: Melbourne).

Maiden, J.H., \& E. Betche (1916) Census of New South Wales Plants. (Government Printer: Sydney). Makinson, R.O. (1996) Grevillea. Pp. 845-870 in N.G. Walsh \& T.J. Entwisle (eds), Flora of Victoria, vol. 3. (Inkata Press: Melbourne).

Molyneux, W.M., \& P. Olde (1994) Delimitation of two new species from the Grevillea victoriae alliance (Proteaceae: Grevilleoideae). Telopea 5(4): 781-787.

Mueller, F. (1855a). Descriptive characters of new alpine plants from continental Australia. Trans. Philos. Soc. Victoria 1: 96-111.

Mueller, F. (1855b). Description of new Australian plants chiefly from the Colony of Victoria. Trans. \& Proc. Victorian Inst. 1854-1855: 114-135.

Olde, P., \& N.R. Marriott (1995). The Grevillea Book, vol. 3 (Kangaroo Press: Kenthurst). 